\title{
SOCIO-HISTORICAL IMPORTANCE OF DEVELOPING HYGIENIC CULTURE IN THE PREPARATION OF STUDENTS FOR FAMILY LIFE
}

\author{
Muzayyan Mubashirovna Kholmatova \\ Independent Researcher Kokand State Pedagogical Institute, Uzbekistan
}

\section{ABSTRACT}

The article analyzes the socio-historical significance of the development of hygienic culture in the process of preparing students for family life. Also, the process of preparing students for family life, in this process, the problem of forming a hygienic culture in them is studied.

KEYWORDS:- Hygiene, social value, COVID-19, marriage, immunodeficiency, medical literacy, reproductive

\section{INTRODUCTION}

Today, cleanliness, hygienic culture is one of the basic individual and social values that lead to the future socio-economic and cultural development of society. The tradition of medical culture, health and healthy living, which is the most important foundation of hygienic culture, is emphasized in the Charter of the World Health Organization, the Ottawa Charter on Health Promotion, and the Bangkok Charter on Health Promotion in a Globalized World [1]. UN UnderSecretary-General Amina Muhammad stressed that the health of the population and its medical culture are directly related to its hygienic culture. He said hygiene played an important role in preventing the spread of infectious diseases during the COVID-19 pandemic. The establishment of the Fund for Sanitation and Hygiene under the United Nations Project
Services Agency (UNOPS) on November 17, 2020 to accelerate reforms in this area [2] also shows the urgency of the problem. The strategic potential of the attitude to medical culture as a value requires the study of the ideal directions of its development in the world, the state, individuals, and most importantly in the younger generation.

In the world of pedagogical research, the process of preparing young people, especially students, for family life, the priority of studying the problem of forming a hygienic culture in them, arises due to changes in modern human lifestyles and high rates of chronic diseases. The importance of studying the social and pedagogical factors of human lifestyle is related to the ability to prevent or reduce various hygienic hazards by changing human behavior. The majority of the world's population still does not have access to sustainable hygienic 
CURRENT RESEARCH JOURNAL OF PEDAGOGICS 2(6): 51-56, June 2021

DOI: https://doi.org/10.37547/pedagogics-crjp-02-06-11

ISSN 2767-3278

(C)2021 Master Journals

\section{Crossref do) 81 Google}

Accepted 11 thJune, 2021 \& Published $16^{\text {th }}$ June, 2021

conditions. In addition, 892 million people still need to defecate outdoors, and 620 million children attend schools without toilets. Every fifth hospital in the world does not have a toilet and water. "If you don't have a toilet in your house, how can you provide insulation and hygiene during a pandemic? This is especially difficult for girls and women, "said UNICEF President Henrietta For. According to him, the use of sanitary facilities in the family, schools and hospitals is a necessity, not a luxury. He said the opportunity would bring huge dividends to the world. Therefore, in order to effectively promote and teach the hygienic culture, the attitude of students to the attitude to health and cleanliness as a value as a socio-pedagogical factor is becoming increasingly relevant in the context of the pandemic.

In the process of preparing students for family life in our country, the development of a hygienic culture in them is an important link in the reform of the education system, which is now a priority of the development strategy of our country.

\section{Materials AND Methods}

Law of the Republic of Uzbekistan "On State Youth Policy" No. ZRU-406 of September 14, 2016, Cabinet of Ministers of the Republic of Uzbekistan No. 251 of August 29, 2015 "On the concept and measures to ensure healthy nutrition in 2015-2020" - Resolution "On approval of a set of measures", Resolution No. 132 of May 2, 2016 "On the organization of healthy eating in general secondary and secondary special, vocational education institutions", Resolution No. 2909 of April 20, 2017 "On further development of the higher education system The main content of this article is to fulfill the tasks set by the Decree of the Cabinet of Ministers of the Republic of Uzbekistan dated May 27, 2019 No 434 "On approval of the Concept of development of environmental education in the Republic of Uzbekistan."

Healthy thinking, socio-philosophical aspects of healthy culture in our country in the researches of T.Mahmudov, S.Otamurodov, A.Ochildiev, J.Tulenov, S.Shermuhamedov, E.Yusupov, A.Erkaev, U.Karabaev, some psychological features G.Shoumarov, It has been studied in the research works of such scientists as V.Karimova, E.Gaziev, N.Safoev, Z.Nishonova.

The issues of healthy lifestyle and hygienic education, family upbringing have been studied in detail in the research work of O.Musurmonova, D.Sharipova, M.Mahmudova, S.R.Mukhamedieva, F.Abdurahimova, T.Ulmatkulov.

\section{Results AND DISCUSSION}

The family, as the smallest but most important part of society, plays a major role in human life. The level of socialization of a person, especially young people, the spiritual image is formed primarily in the family. The consistent social policy of the state is also primarily aimed at ensuring the well-being of the people, strengthening the peaceful life of this country. In this regard, among the aspects of forming a healthy family among young people, one of the problems in the formation of mental readiness is the correct understanding of the attitude of young people to the family and marriage, the concept of their role in modern society.

Different aspects of the family make different sense for an individual. The family fully provides a person mentally and physically, acts as a "emotional restraint". Man feels his need and worth in the family.

It is no coincidence that people say that "health is a priceless wealth." Only when the human body is healthy can it think deeply and function productively. It is said in the Qur'an, "Everything depends on intention." Only when everyone 
CURRENT RESEARCH JOURNAL OF PEDAGOGICS 2(6): 51-56, June 2021

DOI: https://doi.org/10.37547/pedagogics-crjp-02-06-11

ISSN 2767-3278

(C)2021 Master Journals

\section{Crossref do) 81 Google}

Accepted 11 thJune, 2021 \& Published 16 ${ }^{\text {th }}$ June, 2021

sincerely intends to be healthy and live a long life, to see healthy children and grandchildren, will he be able to build a peaceful, prosperous life in his family and strive to create the necessary conditions. To do this, first of all, it is necessary to form a healthy lifestyle in the family. It is human health that is a key factor in shaping a healthy family.

In our country, the family has long been considered a sacred homeland. Family life is a healthy lifestyle and living as an unmarried couple is prohibited. The main goal of marriage is to have a healthy child, to bring him up as a mature person and to continue a healthy generation. In ancient times, when Uzbeks wanted to marry a boy and have a girl, they tried to get married to healthy families by asking about the seven pillars of their future marriage. In doing so, they have ensured the health of the next seven generations, both physically and spiritually. Today, the purpose of premarital medical examination of young people is to create a healthy family. When the parents are healthy, a healthy child is born.

In order to form a healthy family and prevent the birth of children with congenital and hereditary diseases, the Cabinet of Ministers adopted Resolution No. 365 of 25 August 2003 "On approval of the Regulations on medical examination of married persons." This decision has been implemented since January 1, 2004.

Paragraph 6 of Annex 1 to the Regulation states that two young men, girls and boys must undergo a free medical examination within two weeks from the date of application to the medical institution for a medical examination after applying to the FXDYo department. Medical certificate and referrals must be completed separately for each spouse (according to Annex 3 to the Regulations).

Married people are medically examined in 5 areas - mental illness, drug addiction, trauma, tuberculosis and HIV (human immunodeficiency virus), AIDS (Acquired Immune Deficiency Syndrome). A centralized family clinic in each district provides medical services for newlyweds. The person to be married will be notified of the results of the medical examination by the responsible officer of the medical institution and will be explained the possible consequences of the identified diseases in the above five areas after the marriage and the marriage after treatment.

One of the important directions in the adopted state programs is the development of the movement "Healthy mother - healthy child", advocacy among young people.

It is known that the most basic functions of motherhood are reproductive and educative functions. Reproductive functions are related to the reproductive health of the expectant mother and the birth of a healthy child. The functions of an educator include child care, upbringing, education, and so on.

In addition, there is the economic function of the family. Improving the living standards of families is a priority of economic policy of our country. In implementing this policy, it is important that the state creates sufficient opportunities for the population to overcome economic difficulties. To this end, the state has created all conditions for the active participation of the population in economic processes and the development of private entrepreneurship.

In short, the study of the socio-demographic situation of the family plays an important role in determining the future lifestyle of society, the social, economic and demographic prospects of the population.

- The family is an environment, a force that drives development, influencing the current processes of political, socioeconomic and cultural-spiritual renewal. 
That is why mature and strong families in all respects are the greatest wealth of the country.

- $\quad$ Therefore, it is very important to prepare young people for future life in family life, to inculcate in them the values of family and marriage, to form a healthy family and to provide them with the knowledge necessary to create a healthy family environment. Because the stability of family relations ensures the economic and social development of society, as well as plays an important role in improving demographic processes.

- $\quad$ The work carried out in the following areas requires special attention:

- $\quad$ Strengthening young people's sense of responsibility for family life;

- Increasing the social prestige of fatherhood and motherhood;

- Strengthening the psychological preparation of young people for family life;

- Forming in young people a sense of love, the right attitude to family and marriage;

- Inculcate knowledge of reproductive health and reproductive culture in young people;

- $\quad$ Strengthening the institution of the family, family-marriage relations, raising the value of the family among young people, the widespread promotion of family and marriage values, the preservation of social and cultural traditions in the process of generational change.

The issue of increasing medical literacy in the family is of great practical importance in shaping a healthy lifestyle and protecting the health of the nation. According to the Republican Center for Reproductive Health, maternal mortality is 5 times higher under the age of 20 and over 35 years. It is also said that a mother over the age of 35 is 30 times more likely to give birth to a child with Down syndrome. Only 30\% of women maintain an acceptable intergenetic interval ( 3 years). The abortion rate is also high, equal to the number of births. $60-70 \%$ of women of childbearing age suffer from some extragenital diseases. To overcome the above-mentioned problems, everyone should have full information to strengthen reproductive health, to form a family in terms of quality and size, to take advantage of modern, effective technologies.

Creating a healthy family is a serious and complex task in all respects. In order to fulfill this important task, it is necessary to achieve a high level of reproductive culture in the family. Research shows that women's knowledge of reproductive health is not adequate. Therefore, it is necessary to adequately promote popular and interesting information on reproductive health and to intensify the work in this area, to improve the cooperation of experts in the field, governmental and non-governmental organizations.

It is also necessary to constantly monitor the problems of young families, including divorce, unhealthy family environment, unemployment, migration, to create an effective system of studying these issues, to involve experts in finding solutions to these problems based on the materials studied, "live" results. It is advisable to present the recommendations to young people, professionals, parents and the general public in the form of manuals, popular science brochures, as well as booklets.

A responsible approach to the process of preparing young people for family life is a requirement of today, and the work in this direction should be carried out systematically and consistently, including the Women's Committee, "Kamolot" Youth Movement, "Family" IAM, "Mahalla" and "Soglom Avlod" 
foundations. and cooperation between other organizations should be strengthened. In order to prepare young people for family life in the regions and increase the medical, social and legal knowledge of young families, the establishment and constant monitoring of the activities of "Young Family" schools gives good results.

It is necessary to strengthen the process of educating young people and enriching their spiritual world in preschools, schools, colleges, lyceums and universities on the basis of national traditions and historical sources.

It is expedient to study the economic situation of young families, to improve the system of financial support for low-income families, to attract sponsors to provide financial support for weddings of children from low-income families.

Also

- Formation of a healthy family, development of measures to improve the reproductive health system, expansion of medical patronage services for young families living in remote areas of the country with the organization of trains "Ecosan" and "Health";

- Promoting a healthy lifestyle and the importance of premarital health care among young people in order to prevent infertility, birth defects, maternal or infant mortality;

- In-depth specialized medical examination and rehabilitation of third-year students of academic lyceums and professional colleges, submission of medical examination results to parents (or introduction to parents) to strengthen the health of young people, to form a healthy generation and a healthy family in the future;

- In order to prevent the establishment of sharia marriages and paternity, the organization of mobile registration of marriages of young people once a month in the mahallas far from the bodies of the Civil Registry Office;

- $\quad$ Creating benefits, places for children from young families to place in kindergarten;

- $\quad$ Conduct regular propaganda and advocacy work through the media. The Republican Center for Reproductive Health, together with all medical workers, the Republican Women's Committee, the Fund "For Healthy Generation", the Fund "Mahalla" and other community organizations should further improve their activities.

- It is necessary to establish social partnership between government agencies and NGOs in promoting and encouraging the formation of a healthy family.

- The role of the Kamolot youth social movement is also important in this regard. The movement faces the following goals in this regard. These are:

- $\quad$ Raising the morale of young families on the basis of national and universal values, studying and popularizing the heritage of ancestors;

- Collection and compilation of statistics on young families;

- Development and implementation of effective and acceptable methods of spiritual and educational work aimed at improving the legal, medical, physical and spiritual culture of young families;

- Regular holding of various contests and sports competitions among young families;

- Establishment of legal, medical, psychological counseling for young families;

- $\quad$ Carrying out explanatory and propaganda 
CURRENT RESEARCH JOURNAL OF PEDAGOGICS 2(6): 51-56, June 2021

DOI: https://doi.org/10.37547/pedagogics-crjp-02-06-11

ISSN 2767-3278

(C)2021 Master Journals

\section{Crossref dof 80 Google}

Accepted 11 th June, 2021 \& Published $16^{\text {th }}$ June, 2021

work aimed at increasing the responsibility of the young family for the birth of a healthy offspring and the upbringing of a healthy generation;

- Organization of special training courses aimed at forming a culture of healthy living of young families;

- Preparation of methodological manuals and booklets, popular science brochures and explanatory work on family problems and their solutions;

- $\quad$ Carrying out practical activities aimed at preparing young people for family life in educational institutions;

- Establish cooperation with government and public organizations to provide comprehensive support to young families;

- Ensuring the implementation of the measures set out in the Government decisions on the welfare of young families;

- Develop an implementation mechanism and procedure for the Action Systems to promote and encourage the formation of a healthy family among young people.

In carrying out this work, it would be expedient to develop a targeted program "Young Family".

In conclusion, we would like to emphasize that the Nightmare says about family upbringing: "If a man is not made wise by his master, no wise man should bother to teach him the word, his labor will be wasted." According to the Eastern thinker Abu Ali Ibn Sina, justice is related to the concepts of balance and moderation, which are formed primarily in family relations.
мире//Официальный сайт Всемирной организации здравоохранения. URL: http://www.who.int/healthpromotion/co nferences Оттавская хартия по укреплению здоровья, 1986 г.//Официальный сайт Европейского регионального бюро Всемирной организации здравоохранения. URL: http://www.euro.who.int/_data/assets (дата обращения: 10.10.16); Устав (Конституция) Всемирной организации здравоохранения [Электронный ресурс]//Сайт Всемирной организации здравоохранения. URL: http://who.int/ru/ (дата обращения: 15.12.2016); The Bangkok Charter for Health Promotion in a Globalized World//Официальный сайт Всемирной организации здравоохранения. URL: http://www.who.int/healthpromotion/co nferences/ (дата обращения: 10.10.16)

2. https://news.un.org/ru. В ООН создан Фонд по гигиене и санитарии. 17 ноября 2020.

3. https://www.gazeta.uz. БМТда Гигиена ва санитария жамғармаси ташкил этилди. 2020 йил 18 ноябрь.

4. Сиддиков, И. Б. (2019). Государственная политика в отношении молодежи в Узбекистане: национальный опыт и реальная необходимость международных инициатив. In Условия социально-экономического развития общества: история и современность (рр. 38-43).

\section{REFERENCES}

1. Бангкокская хартия укрепления здоровья в глобализованном 